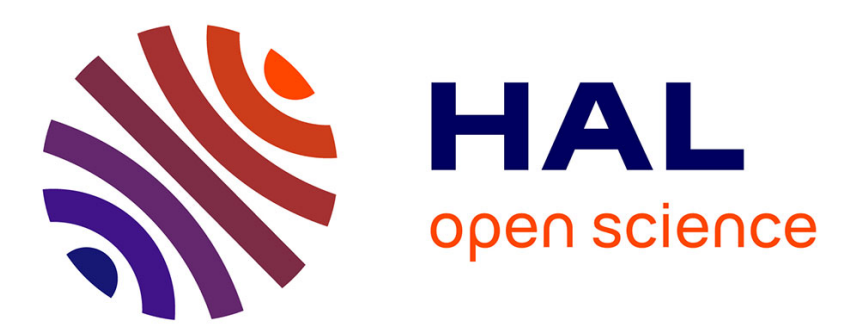

\title{
Vapour Growth of Micro-Coiled Ceramic Fibers and their Properties
}

S. Motojima, I. Hasegawa, H. Iwanaga

\section{To cite this version:}

S. Motojima, I. Hasegawa, H. Iwanaga. Vapour Growth of Micro-Coiled Ceramic Fibers and their Properties. Journal de Physique IV Proceedings, 1995, 05 (C5), pp.C5-1061-C5-1068. 10.1051/jphyscol:19955125 . jpa-00253821

\section{HAL Id: jpa-00253821 https://hal.science/jpa-00253821}

Submitted on 1 Jan 1995

HAL is a multi-disciplinary open access archive for the deposit and dissemination of scientific research documents, whether they are published or not. The documents may come from teaching and research institutions in France or abroad, or from public or private research centers.
L'archive ouverte pluridisciplinaire HAL, est destinée au dépôt et à la diffusion de documents scientifiques de niveau recherche, publiés ou non, émanant des établissements d'enseignement et de recherche français ou étrangers, des laboratoires publics ou privés. 
JOURNAL DE PHYSIQUE IV

Colloque C5, supplément au Journal de Physique II, Volume 5, juin 1995

C5-1061

\title{
Vapour Growth of Micro-Coiled Ceramic Fibers and their Properties
}

\author{
S. Motojima, I. Hasegawa and H. Iwanaga* \\ Department of Applied Chemistry, Faculty of Engineering, Gifu University, Gifu 501-11, Japan \\ * Faculty of Liberal Arts, Nagasaki University, Nagasaki 852, Japan
}

\begin{abstract}
Micro-coiled fibers of carbon, $\mathrm{SiC}, \mathrm{Si}_{3} \mathrm{~N}_{4}, \mathrm{TiC}, \mathrm{ZrC}$ and $\mathrm{HfC}$ were prepared by a metal-impurity activated chemical vapor deposition or vapour phase metallizing of the coiled carbon fibers. The growth conditions, morphology, growth mechanism and some properties were examined. The double-coiled carbon fibers were prepared using acetylene as a carbon source and various powders or plates of transition metals, metal carbides, $\mathrm{MoS}_{2}, \mathrm{Ti}_{2} \mathrm{O}_{3}$, and triple-coiled SiC fibers were prepared using coked rice husks and/or $\mathrm{SiO}$ as a $\mathrm{Si}$-source and $\mathrm{Ni}, \mathrm{Cr}$ or $\mathrm{Fe}$ as a catalyst at $1400-1500^{\circ} \mathrm{C}$. The double-coiled TiC fibers were prepared by the $\mathrm{PCl}_{3}$ activated $\mathrm{CVD}$ process on a graphite substrate using a $\mathrm{Pt}+\mathrm{Si}$ or $\mathrm{Pd}+\mathrm{Si}$ mixed catalyst at $1050-1250^{\circ} \mathrm{C}$.
\end{abstract}

1. Introduction

Industrially available raw materials or functional materials with a micro-coiled or helical morphology are not currently available. However, we can expect novel functional properties from such coiled materials. For example, the coiled fibers of carbon or metal carbides are potential candidates for fillers in electromagnetic shielding materials, micro-elastic packing or filter materials resistant to high temperatures and/or harsh or corrosive environments, micromechanical elements such as microsprings, micro sensors, etc.

The growth of carbon fibers by the catalytic decomposition or disproportionation of organic vapours or $\mathrm{CO}$ have been reported by many researchers [1-7]. However, the obtained fibers were generally straight and/or tubular with a somewhat helical form.

We obtained micro-coiled carbon fibers (abbreviated "carbon coils" herefter) by the catalytic pyrolysis of acetylene [8-10]. Furthermore, we obtained regularly micro-coiled $\mathrm{Si}_{3} \mathrm{~N}$ fibers by the metal impurity-activated CVD process using $\mathrm{Si}_{2}^{4} \mathrm{Cl}_{6}[11-12], \mathrm{SiO}_{2}+\mathrm{C}$ or $\mathrm{SiO}$ [13] as the $\mathrm{Si}$ source at $1200-1500^{\circ} \mathrm{C}$. The coiled fibers of SiC [14-16] or $\mathrm{TiC}[14,17]$ were obtained by the CVD process or the metallizing of the coiled carbon fibers. However, their preparation conditions, morphology and properties have not been examined. 
In this work, micro-coiled fibers of carbon, $\mathrm{SiC}, \mathrm{Si}_{3} \mathrm{~N}_{4}$, and metal carbides were obtained from vapour phase using the metal-impurity catalyzed chemical vapor deposition process or by the vapour phase metallizing of the coiled carbon fibers. The growth conditions, morphology, growth mechanism and some properties were examined.

\section{Experimenta1}

A graphite plate substrat, on which metal powder as a catalyst was uniformly dispersed, was placed in the central part of a horizontal reaction tube (quartz or mullite, $30 \mathrm{~mm} i . d$. ) which was heated from the outside. A metal plate was also used as the substrate and catalyst for preparation of the carbon coils. The source gas system used for the preparation of respective fibers were as follows.

$\mathrm{C}_{2} \mathrm{H}_{2}+\mathrm{H}_{2}+\mathrm{Ar}+$ thiophene carbon coils

(Coked rice hulls and/or $\mathrm{SiO})+\mathrm{H}_{2}+\mathrm{CH}_{4} \longrightarrow \mathrm{SiC}$ coils

(Coked rice hulls and/or $\mathrm{SiO})+\mathrm{H}_{2}+\mathrm{NH}_{3} \longrightarrow \mathrm{Si}_{3} \mathrm{~N}_{4}$ coils

$\mathrm{TiCl}_{4}+\mathrm{PCl}_{3}+\mathrm{H}_{2}+\mathrm{C}$ (graphite substrate) ${ }^{3} \longrightarrow \mathrm{TiC} \stackrel{4}{\text { coils }}$

$\mathrm{HfCl}{ }_{4}+\mathrm{PCl}_{3}+\mathrm{H}_{2}^{2}$ Ar+C(graphite substrate) $\rightarrow \mathrm{HfC}$ coils

Carbon coils $+\mathrm{ZrCl}_{4}+\mathrm{H}_{2} \longrightarrow \mathrm{ZrC}$ coils

3) Results and discussion

3.1) Coiled carbon fibers: Commercial acetone-dissolved acetylene (97-99\% purity), in which a small amount of thiophene gas was added, was used without further purification. The gas flow rates were fixed as follows; $\mathrm{C}_{2} \mathrm{H}_{2} 30 \mathrm{sccm}, \mathrm{H}_{2} 70 \mathrm{sccm}$ and $\mathrm{Ar} 40 \mathrm{sccm}$. The effect of reaction temperature on the coil yield is shown in Fig.1, in which $\mathrm{Ti}$ powder was used as the catalyst and thiophene gas flow rate was fixed at $0.34 \mathrm{sccm}$. It was observed that the maximum coil yield (about $30 \%$ ) was obtained at $775^{\circ} \mathrm{C}$ and the coil yield outstandingly decreased above or below this temperature. The effect of thiophene gas flow rate on the coil yield was shown in Fig.2, in which reaction temperature was fixed at $775^{\circ} \mathrm{C}$. It was observed that the maximum coil yield (about 54\%) was obtained at $0.47 \mathrm{sccm}$ and the yield outstandingly decreased above or below this value. These results indicate that the growth conditions of the carbon coils were restricted within very narrow ranges. We examined the optimum growth conditions for growing carbon coils, at which maximum coil yield was obtained, using various metal powder catalysts, and the results are shown in Table 1 . It can be seen that among used metal catalysts, $\mathrm{Ti}, \mathrm{Ni}$ and $\mathrm{W}$ were the most effective for obtaining carbon coils with higher yield. The optimum reaction temperatures and thiophene gas flow rates were $700-850^{\circ} \mathrm{C}$ and $0.14-0.47 \mathrm{sccm}(0.1-0.3$ vol\% in total gas), respectively. We have observed that, using oxygen free Ti plate which was etching-treated by conc. HC1 solution, the coil yield was very low or nearly zero. On the other hand, Ti powder which was pre-oxidation treated at $850^{\circ} \mathrm{C}$ for $30 \mathrm{~min}$ in air have some catalytic effects for growing carbon coils and the maximum coil yield of about $27 \%$ was obtained. Furthermore, we have found that $\mathrm{Ti}_{2} \mathrm{O}_{3}$ powder was also effective for growing carbon coils and the maximum coil yield of $13 \%$ was obtained. However, the carbon coils could not obtained using $\mathrm{TiO}_{2}$ or $\mathrm{TiO}$ powders. These results suggest that surface oxide layers formed on the metal catalyst have some important 
role for growing carbon coils as like as strong catalytic effect of iron suboxide for growing straight carbon fibers from a vapor phase [18].

Figure 3 shows the morphology of representative carbon coils obtained using a $\mathrm{Ni}$ powder as the catalyst. The coiling morphology of the carbon coils obtained using metal catalysts other than $\mathrm{Ni}$ were also similar to that of Fig.3. A Ni grain usually observed on the tip of carbon coils obtained using the Ni catalyst was identified to be a $\mathrm{Ni}_{3} \mathrm{C}$ phase by a XRD and electron diffraction. The presence of metal carbide phase corresponding to the used metal as the catalyst were also observed on the tip of the carbon coils. That is, it may be reasonably considered that metal carbide acts as an actual catalyst for growing carbon coils. We examined the catalytic effect of various metal carbide powder on the growth of the carbon coils. Among metal carbides used, only TiC powder was effective for obtaining carbon coils. However, the maximum coil yield was only $14 \%$, which is very low value compared to that obtained using the $\mathrm{Ti}$ metal catalyst of $54 \%$.

3.2) TiC coils: We obtained micro-coiled TiC fibers (abbreviated "TiC coils" hereafter) from a gas mixture of $\mathrm{TiCl}_{4}+\mathrm{H}_{2}+\mathrm{PCl}_{3}+\mathrm{Ar}$ at $1050^{\circ} \mathrm{C}$ on a graphite substrate using the mixed impuirties of Si+Pd on a graphite substrate. Figure 4 shows the representative TiC coils obtained among TiP whiskers. The TiC coils were in a polycrystalline state with a $1-5 \mu \mathrm{m}$ coil diameter and $20-150 \mu \mathrm{m}$ coil length. The TiC coils were generally double coils similar to the carbon coils. The carbon source of $\mathrm{TiC}$ coils is considered to be graphite substrate. The effect of $\mathrm{PCl}_{3}$ or $\mathrm{HCl}$ by-produced by the hydrogen reduction of $\mathrm{PCl}_{3}$ on the vapourization of carbon and/or growth of the TiC coils are not yet known.

3,3) $\mathrm{Si}_{3} \frac{\mathrm{N}}{4}$ coils: Micro-coiled $\mathrm{Si}_{3} \mathrm{~N}_{4}$ fibers (abbreviated "Si ${ }_{3} \mathrm{~N}_{4}$ coils" herezter) was obtained from a gas mixture of $\mathrm{SiO}-\mathrm{HN}_{3}-\mathrm{H}_{2} \mathrm{Ar}^{34}$ using a $\mathrm{Co}$ or $\mathrm{Fe}$ metal catalyst. Representative $\mathrm{Si}_{3} \mathrm{~N}_{4}$ coils obtained is shown in Fig.5. The $\mathrm{Si}_{3} \mathrm{~N}_{4}$ coils were a single coil of an amorphous state having a $10-20 \mu \mathrm{m}$ coil diameter and $100-1500 \mu \mathrm{m}$ coil length. The $\mathrm{Si}_{3} \mathrm{~N}_{4}$ coils showed a maximum shear stress of about $12 \mathrm{GPa}$ and the regidity of $110 \mathrm{GPa}$.

3.4) SiC coils: Micro-coiled SiC fibers (abbreviated "SiC coils" hereafter) were sometimes observed among amorphous straight SiC fibers. The SiC coiled fibers were generally triple-coiled or three-braided fibers in which three fibers were entwisted each other. The coil diameter was $0.3-1 \mu \mathrm{m}$ and coil length was $5-50 \mu \mathrm{m}$. Some of the triple-coiled SiC fibers are shown in Figs. 6 and 7 . Two kind of coiling patterns were generally observed. One pattern is that of very regurally and densely coiled fibers as shown in Fig. 6 . The coil diameter was about $0.5 \mu \mathrm{m}$ and length was 5-30 $\mu \mathrm{m}$. Three fibers ( $A, B$ and $C$ ) grew from a bulk deposit (arrow in Fig.6b) and entwisted each other to from triple-coiled SiC fibers. Another type is a relatively loosely coiled fibers with a wide coil pitch such as three braids (Fig.7). Some of closing parts were coalesced each other as shown in Fig.7b. This observation suggests that in the first place thin triple coils grew to the fiber growth axis with very high speed, and then the coils grew to the radial direction 
with very low speed to form coalesced part. Single-coiled SiC fibers were rarely observed, eventhough sine-curved fibers which was coiled with very large coil pitch of $5-20 \mu \mathrm{m}$ were frequently observed. Growth mechanism of these triple-coiled SiC fibers are not yet known.

3.5) HfC coils: The HfC coils grew sometimes among HfP whiskers from a gas mixture of $\mathrm{HfCl}_{4}+\mathrm{C}$ (graphite substrate) $+\mathrm{H}_{2}+\mathrm{PCl}_{3}+\mathrm{Ar}$ on a graphite substrate. Representative micrograph of the HfC coils obtained is shown in Fig.8.

3.6) ZrC coils: Micro-coiled $\mathrm{ZrC}$ fibers were obtained by the vapour phase zirconizing of the carbon coils at $1100-1250^{\circ} \mathrm{C}$ using $\mathrm{ZrCl}_{4}+\mathrm{H}_{2}+\mathrm{Ar}$ gas mixtures. Representative $\mathrm{ZrC}$ coils obtained is shown in FIg.9. The coiling morphology of the source carbon coils were perfectly preserved after zirconizing at high temperatures.

\section{Acknowledgement}

This work was supported by The Iketani Science and Technology Foundation, The Kai Sangyo Gizyutsu Shinko Zaidan, The Mitsubishi Foundation, The Murata Science Foundation, and The Yazaki Memorial Foundation for Science and Technology.

\section{References}

1) W. R. Davis, R. J. Slawson and G. R. Rigby, Nature, 171, 756(1953).

2) W. R. Davis, R. J. Slawson and G. R. Rigby, Trans. Brit. Ceram. Soc., 56, 67(1957).

3) R. T. K. Baker, M. A. Barber, P. S. Harris, F. S. Feates and R. J. Waite, J. Cata1., 26, 51(1972).

4) L. S. Lobo and D. L. Trimm, J. Cata1., 29, 15(1973).

5) R. T. K. Baker and R. J. Waite, J. Catal., 37, 101(1975).

6) M. Hillert and N. Lange, Z. Krist., 111, 24(1958).

7) J. Caluszka and M. H. Back, Carbon, 22, 141(1984).

8) S. Motojima, S. Ueno, T. Hattori and K. Goto, Appl. Phys. Lett., $54,1001(1989)$.

9) S. Motojima, S. Ueno, T. Hattori and H. Iwanaga, J. Cryst. Growth, 96, 383(1989).

10) S. Motojima, et al., unpublished results.

11) S. Motojima, M. Kawaguchi, K. Nozaki and H. Iwanaga, Appl. Phys. Lett. , 56, 321(1990).

12) S. Motojima, M. Kawaguchi, K. Nozaki, and H. Iwanaga, Carbon, 29, 379(1991).

13) S. Motojima, I. Hasegawa, S. Kagiya, M. Momiyama, M. Kawaguchi and H. Iwanaga, App1. Phys. Lett., 62, 2322(1993).

14) S. Motojima, M. Kawaguchi, K. Nozaki and H. Iwanaga, Proc. 11th Int. Conf. CVD (1990, Seattle), pp. 573-579.

15) A. Addamiano, J. Cryst. Growth, 58, 617(1982).

16) T-K Kang, S-D Park, C-K Rhee and I1-H Kuk, Proc. 6th Japan-Korea Ceramic Seminar (1989, Kobe), p. 249.

17) S. Motojima, I. Hasegawa, M. Kawaguchi, K. Nozaki, and H. Iwanaga, J. Chem. Vapor Deposition, 1, 136(1992).

18) R.T.K. Baker and J.J. Chudzinski, J. Cata1., 64, 464(1980).

19) E. Boellaard, et al., J. Cata1., 96, 454(1985); 96, 468(1985); 96, 481(1985). 

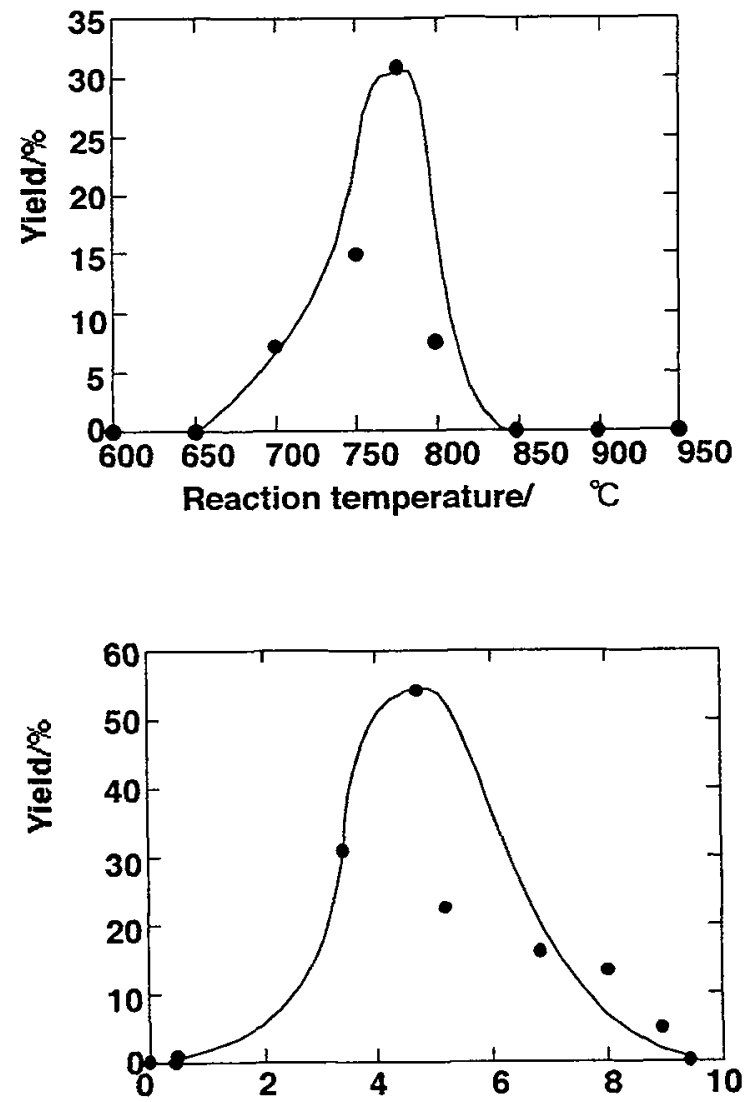

Flow rate of thiophene $/ 10^{2} \mathrm{ml} / \mathrm{min}$
Fig.1. Effect of reaction temperature on the yield of carbon coils. Catalyst: $\mathrm{Ti}$ powder, $\mathrm{C}_{4} \mathrm{H}_{4} \mathrm{~S}$ flow rate: $0.34 \mathrm{sccm}$.
Fig.2. Effect of thiophene gas flow rate on the yield of carbon coils.

Catalyst: Ti powder, Reaction temperature: $750^{\circ} \mathrm{C}$.

\begin{tabular}{cccc}
\hline Catalyst & Fs/10 $0^{2} \mathbf{m l m i n}$ & $\mathrm{RT} / \mathrm{C}$ & Yield/\% \\
\hline $\mathrm{Ti}$ & 47 & 775 & 54 \\
$\mathrm{~V}$ & 24 & 725 & 9.3 \\
$\mathrm{Cr}$ & 24 & 700 & 23 \\
$\mathrm{Mn}$ & 34 & 700 & 2.4 \\
$\mathrm{Fe}$ & - & - & 0 \\
$\mathrm{Co}$ & 14 & $\mathrm{B50}$ & 11 \\
$\mathrm{Ni}$ & 34 & 750 & 49 \\
$\mathrm{Zr}$ & 34 & 750 & 4.8 \\
$\mathrm{Nb}$ & 42 & 750 & 26 \\
$\mathrm{Mo}$ & 14 & 850 & 18 \\
$\mathrm{Hf}$ & 48 & 800 & 7.2 \\
$\mathrm{Ta}$ & 34 & 850 & 18 \\
$\mathrm{~W}$ & 45 & 750 & 55 \\
\hline
\end{tabular}

Table 1. Optimum growth conditions of the carbon coils using various metal powders as a catalyst. 
-sxaqty

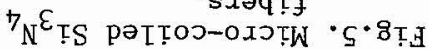

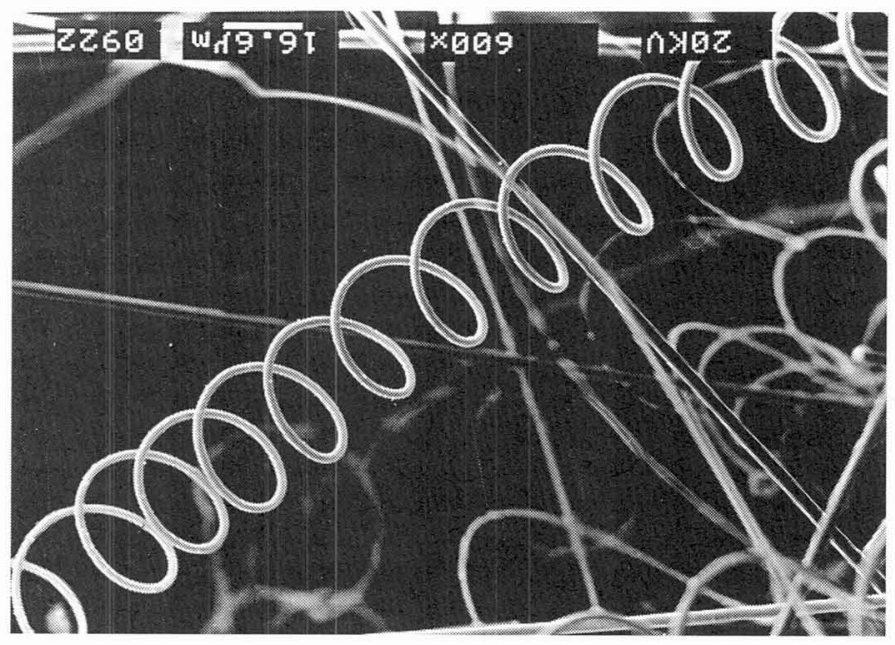

- sxaqII

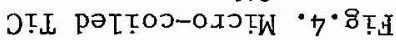

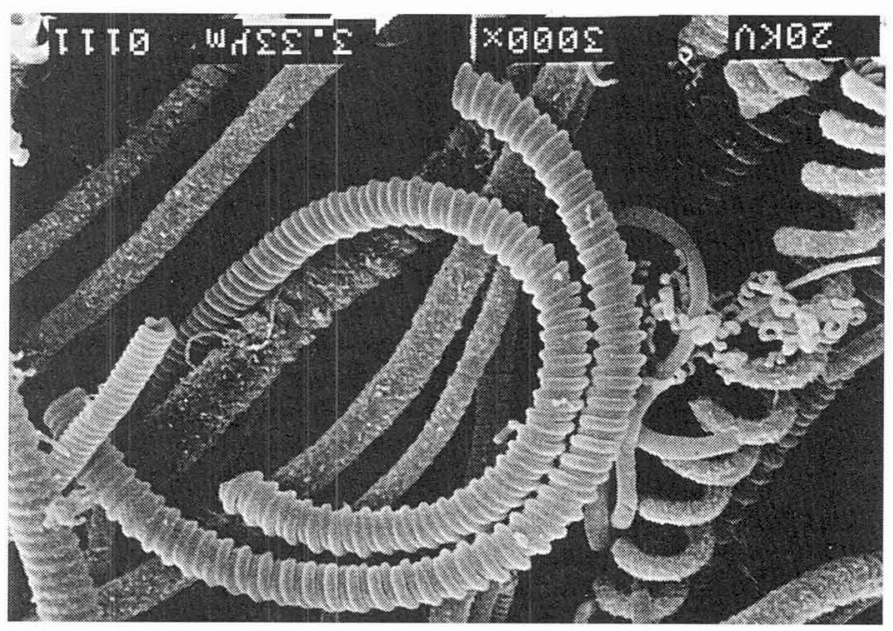

- $s x \partial q$ TI

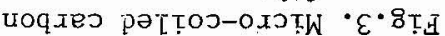

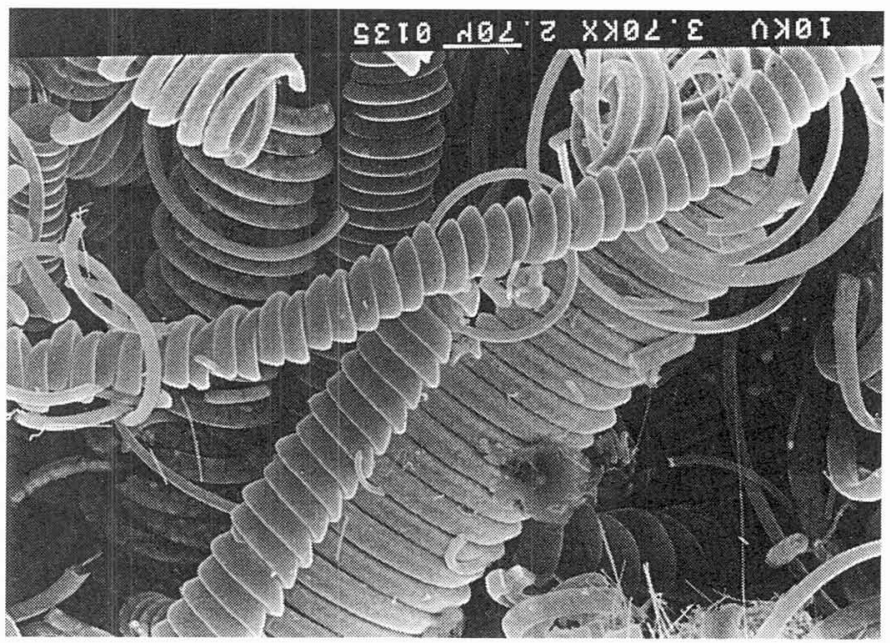


C5-1067
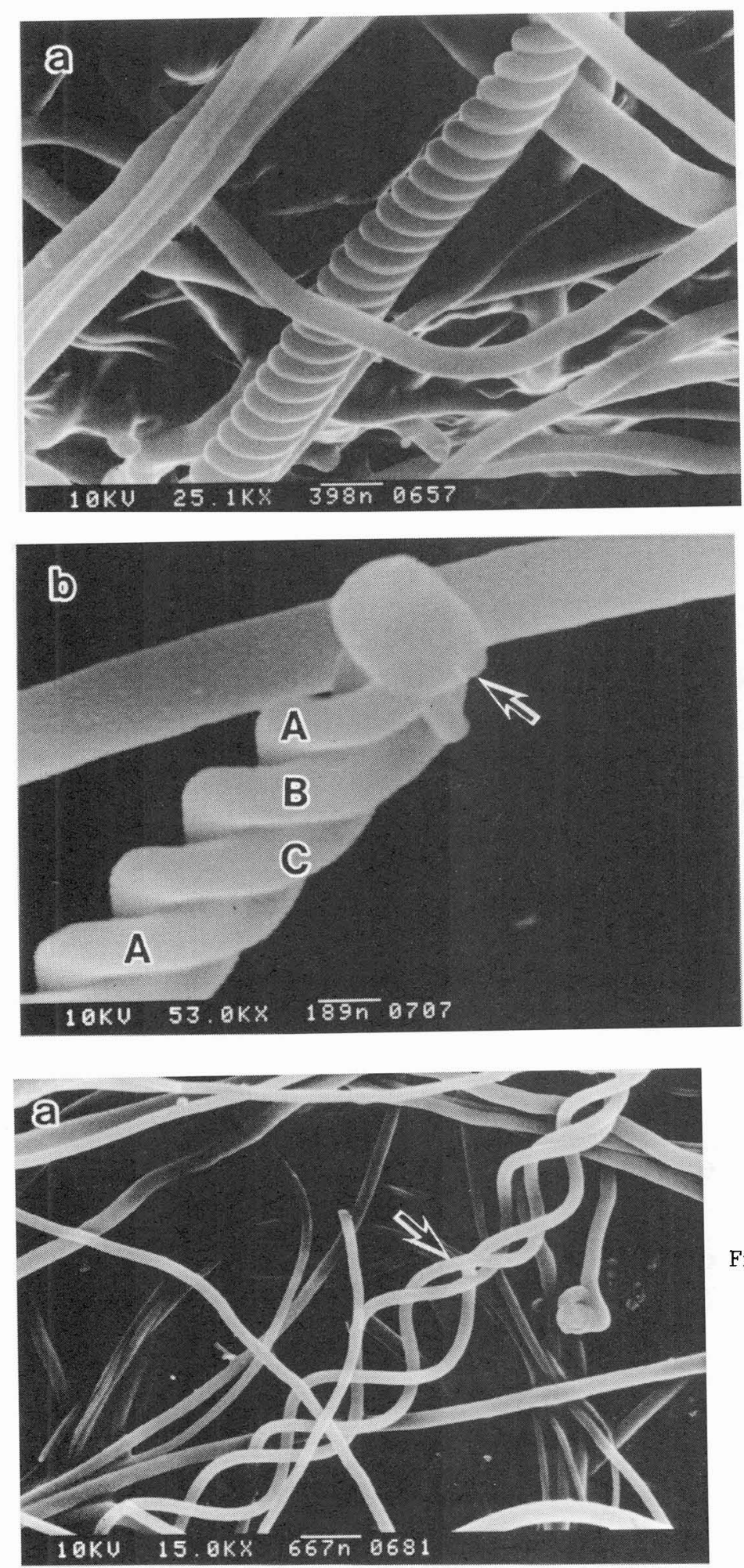

Fig.6. Regularly micro-coiled SiC fibers (a) and the enlarged view of the tip (b).
Fig.7. Three-braided microcoiled SiC fibers (a) and the enlarged view of the crossing part (b). 

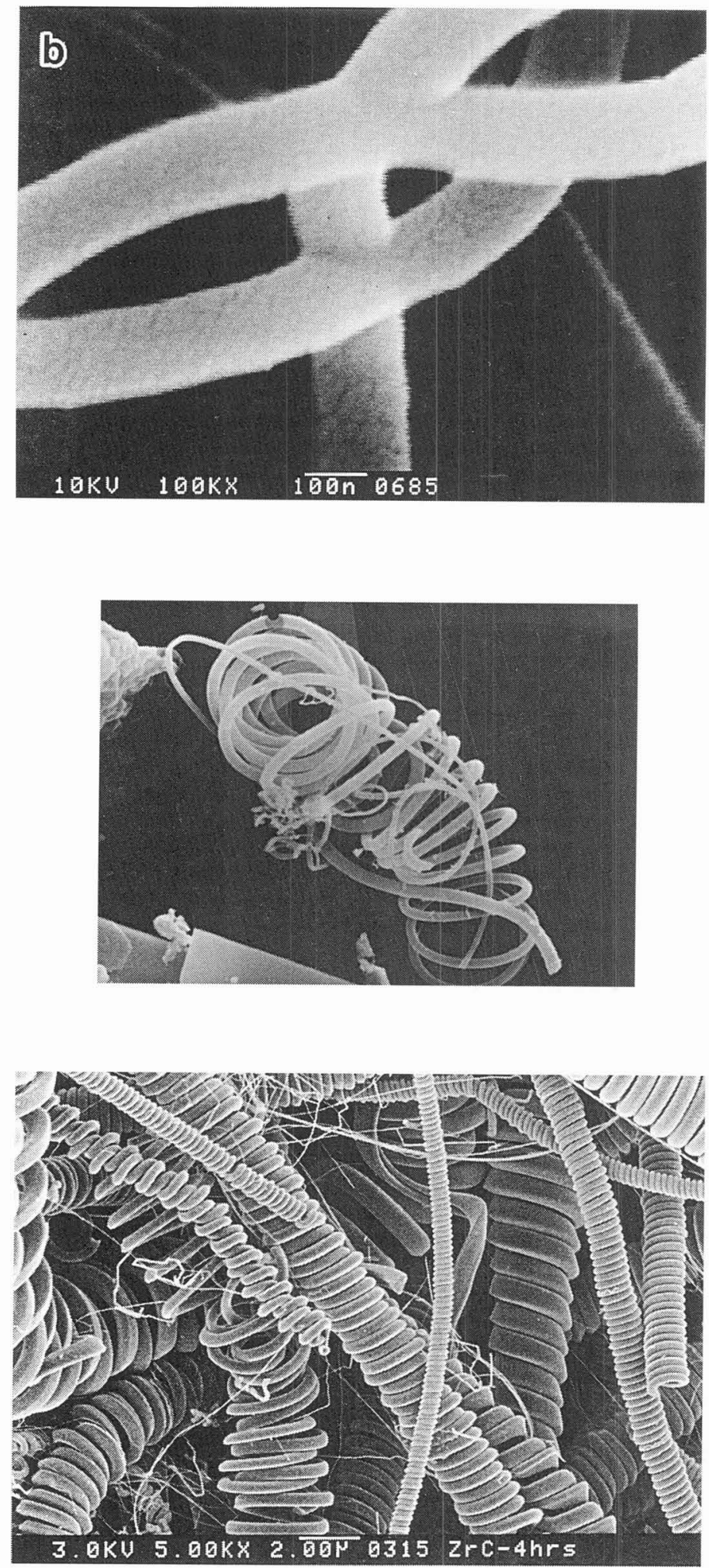

Fig.7. Three-braided microcoiled SiC fibers (a) and the enlarged view of the crossing part (b).

Fig.8. Micro-coiled HfC fibers.

Fig.9. Micro-coiled $\mathrm{ZrC}$ fibers obtained by the vapour phase zirconizing of the micro-coiled carbon fibers. 